\title{
Inflation variability and the relationship between inflation and growth
}

\section{Raghbendra Jha and Tu Dang}

Arndt-Corden Department of Economics, Crawford School of Economics and Government College of Asia and the Pacific, Australian National University

\begin{abstract}
We examine the effect of inflation variability and economic growth using annual historical data on both developing and developed countries. The data cover 182 developing countries and 31 developed countries for the period 1961-2009. Proxying inflation variability by the five-year coefficient of variation of inflation, we obtain the following results: (1) For developing countries, there is significant evidence to suggest that when the rate of inflation exceeds 10 percent inflation variability has a negative effect on economic growth. (2) For developed countries, there is no significant evidence that inflation variability is detrimental to growth.
\end{abstract}

Keywords: Inflation, Growth, Threshold, Variablity JEL Classification: C51, E31, E58. O40p

All correspondence to:

Prof. Raghbendra Jha, Australia South Asia Research Centre, College of Asia and the Pacific H.C. Coombs Building (09) Australian National University, Canberra, ACT 0200, Australia Phone: + 6126125 2683; Fax: + 6126125 0443; Email: r.jha@anu.edu.au 


\section{INTRODUCTION}

The question of link between inflation or inflation variability and economic growth has been widely debated. Some papers, such as Khan and Senhadji (2000), Sarel (1995), Barro (1995) and Fischer (1993), find a non-linear threshold effect in the harmful influences of inflation on growth, i.e., at lower rates of inflation, the relationship between growth and inflation is positive or not significant, but when inflation reaches higher levels it has a significant negative effect on growth. However, the link between inflation variability and growth is far from clear, even in theory. On the one hand, Fischer (1993) argues that inflation uncertainty is a reasonable indicator of economic instability and has a negative effect on economic growth whereas Dotsey and Sarte (2000) find that variability increases average growth through a precautionary savings motive. Thus, Taylor (1993) emphasizes that greater inflation stability comes at the cost of greater output gap variability so policy makers do not face a tradeoff between the level of the output gap and the level of inflation but a variance tradeoff.

Empirical studies also draw mostly contradictory conclusion about the effect of inflation variability. For instance, Fountas and Karanasos (2007) and Fountas (2010) find that inflation is not detrimental to economic growth in industrial countries. However, Narayan, Narayan, and Smyth (2009) show that Chinese output behavior is consistent with the hypothesis that inflation volatility reduces economic growth.

There are several factors that can account for the contradiction in empirical studies on the effects of inflation variability on growth. First, the measure of variability affecting growth is a key to the research results. Normally, inflation variability is measured by the variance or standard deviation of inflation. However, the variance of inflation is highly correlated to its level, making it difficult to distinguish the effects on growth of the level of inflation from the effects of the variability of inflation (Fischer 1993; Khan and Senhadji 2000).

Second, according to Kuang-Liang and Chi-Wei (2010), the empirical results may depend on the sample. In long-run macroeconomic time-series data, structure changes are common.

Third, and most importantly, the effect of inflation variability on growth could vary with the inflation level, i.e., at lower rates of inflation, the effect is not significant, but at higher rates, 
the effect is significantly positive or negative. Ball (1990) argues that once inflation rises above a certain it becomes more uncertain. An explanation for this may be the fact that at a time of high inflation central banks can take either of two decisions: to inflate the economy further to compensate for the new inflation expectation or deflate the economy to release inflationary pressure.

Hence, this paper aims to examine the effect of inflation variability on growth when inflation is high, exceeding a critical point. We assume this critical point is the threshold inflation level at which the inflation - growth relationship transforms from positive (or insignificant) to negative. Such a threshold has recently been detected by intensive research.

However, there is no consensus about the precise threshold of the inflation level. ${ }^{*}$ Sarel (1995) finds evidence of a significant structural break in the inflation — growth relationship, occurring when the inflation rate is 8 percent. Barro (1995) demonstrates that clear evidence of adverse effects of inflation comes at high rates of inflation - above 15 percent. Khan and Senhadji (2000) also find a negative and significant relationship between inflation and growth for inflation above the threshold level of 1-3 percent for industrial countries and 7-11 percent for developing countries. Using a panel data set for industrialized countries Omay and Öznur Kan (2010) find that there exists a statistically significant negative relationship between inflation and growth for the inflation rates above the threshold level of 2.52 percent. Bruno (1995) even find the negative effect of inflation occurs at 40 percent and above. Although, the main purpose of this paper is not to test an existence of a threshold of the inflation, we still detect the inflation threshold for the update database following the method of Khan and Senhadji (2000)..$^{\dagger}$ Subsequently, we investigate the effect of inflation variability on growth.

In this paper, instead of using the variance or the standard deviation of inflation as the measure of inflation variability as in Katsimbris (1985) or Levi and Makin (1980), we use the five-year coefficient of variation of inflation. One reason for preferring the coefficient of variation as the measure of inflation variability is that this gives a feel of the magnitude of the inflation dispersion relative to the level of the inflation. Indeed, there is no doubt that an increase of 1 percentage point in inflation is not remarkable in Vietnam but remarkable in Japan. Another reason for preferring our measure of variability is that, as shown by Figure 1

\footnotetext{
${ }^{*}$ A comprehensive literature review on this topic can obtained from Li (2006).

${ }^{\dagger}$ Which is based on Hansen (1999).
} 
and Logue and Willett (1976), the average rate of inflation and its variability - measured by the variance - tend to be positively correlated. This may introduce multicollinearity when the variance is used with the inflation. Figure 2 shows that there is a no correlation between the coefficient of variation of inflation and the inflation level.

Figure 1 and 2 here.

This paper uses a two stage procedure to examine the relationship between inflation variability and growth. Specifically, we first detect the threshold of inflation level basing on the method of Hansen (1990) in detecting threshold effect in panels, which is applied in Khan and Senhadji (2000) and $\mathrm{Li}(2006)$ and then use the same method to detect the threshold effect of inflation variability which is measured by the coefficient of variation.

The remainder of this paper is organized as follows. Section II introduces the estimation method suggested by the Hansen (1999) and applied by Khan and Senhadji (2000) and (Li 2006). Section III describes the data and presents the summary statistics. Section IV presents the results of the estimation. Section V checks the robustness of the results. Section VI provides some concluding remarks.

\section{ESTIMATION METHOD}

We start with the following specification in Khan and Senhadji (2000) for estimating the threshold $\left(\pi^{*}\right)$ of inflation:

$$
g r o w t h_{t t}=H_{t}+\mu_{t}+\beta_{1} \times \log \left(\pi_{t t}\right)+\beta_{2} \times d^{*}\left[\log \left(\pi_{t t}\right)-\log \left(\pi^{*}\right)\right]+\alpha^{c} X_{t t}+g_{t t}
$$

where, growth is the growth rate of real GDP per capita, $\pi^{*}$ is the threshold of inflation level,

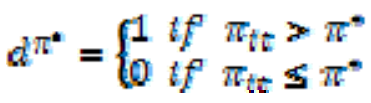

The effect of inflation on growth is given by $\beta_{1}$ for countries in which inflation is less or equal to $\pi^{*}$, and $\beta_{2}$ for countries in which inflation exceeds $\pi^{*}$. From the literature, $\beta_{1}$ is expected to be positive or insignificant, and $\beta_{z}$ is expected to be negative. $X$ are control variables defined as in Khan and Senhadji (2000), Sarel (1995) and Li (2006) and include domestic investment over GDP, government consumption expenditure over GDP, log of 
initial income level, the growth rate of term of trade. The error term $z_{i t}$ is assumed to be independent and identically distributed with zero mean and finite variance. As suggested by Khan and Senhadji (2000), and Sarel (1995) the logarithmic transformation eliminates the strong asymmetry in the inflation distribution. A regression of the level of inflation would give much weight to the extreme inflation observations.

As discussed above, rising from the threshold level $\pi^{*}$ inflation has higher probability of being more uncertain. Thus, we allow discrete slopes to differentiate high-stable and highunstable rates of inflation. We then estimate the following equation:

$$
\begin{aligned}
& \text { growth }_{t i}=\beta_{t}+\mu_{t}+\beta_{1} \times \log \left(\pi_{t t}\right)+\beta_{2} \times d^{\text {gtable }} n^{4}\left[\log \left(\pi_{t i}\right)-\log \left(\pi^{*}\right)\right] \\
& +\beta_{s} \times d^{\operatorname{minatabie} \pi^{*}}\left[\log \left(\pi_{t t}\right)-\log \left(\pi^{*}\right)\right]+\alpha^{c} X_{t t}+g_{t t}
\end{aligned}
$$

where,

$$
\begin{aligned}
& d^{\text {stable } \pi^{*}}= \begin{cases}1 \text { tf } \pi_{t+} \geqslant \pi^{*} \text { AND stable } \\
0 & \text { otherwtse }\end{cases} \\
& d^{\text {unstable } \pi^{*}}= \begin{cases}1 \text { if } \pi_{t-}>\pi^{*} & \text { AND wnstable } \\
0 & \text { otherwise }\end{cases}
\end{aligned}
$$

The effect of inflation on growth is still given by $\beta_{1}$ for countries in which inflation is less or equal to $\pi^{*}, \beta_{2}$ for countries in which inflation exceeds $\pi^{*}$ and is stable, and $\beta_{3}$ for countries in which inflation exceeds $\pi^{*}$ and is unstable. The main purposes of this paper is to estimate and test the significance of $\beta_{2}$ and $\beta_{\mathrm{z}}$. However, the estimators depend on the threshold of inflation level $\pi^{*}$, so first we need to detect the threshold level using the Hansen (1999), which is applied by Khan and Senhadji (2000). This method includes two steps:

(1) We estimate the equation (1) for threshold levels of inflation in a given range, which yield a sequence of residual sum of squared (RSS). The optimal threshold level is the one giving the smallest RSS.

(2) We test the significance of the optimal threshold level by bootstrap method as suggested by Hansen (1999).

After obtaining the threshold of inflation level by implementing the two above steps we carry the same procedure for equation (2) to detect and test the threshold of inflation variability which itself is measured by the coefficient of variation. 


\section{DATA AND SUMMARY STATISTICS}

Our data comes from the World Development Indicator (WDI) database, covering the period 1961-2009, and includes 213 countries (comprising 182 developing countries and 31 developed countries). The data includes the growth rate of real GDP per capita, inflation computed as the growth rate of the CPI index, the initial income level measured as the fiveyear average of GDP per capita in 2000 constant US dollars, government consumption expenditure over GDP, gross capital formation over GDP, terms of trade, the growth rate of money and quasi money (M2).

To reduce business cycle effect and focus on medium and long-term relationship between inflation and growth, our estimations use five-year averages of the panel data based on annual observations. Therefore the time dimension is reduced to 10 observations: $1961-65,1966-70$, 1971-75, 1976-80, 1981-85, 1986-90, 1991-95, 1996-2000, 2001-05, and 2006-09 (the last observation is an average over four years).

Table 1 presents means and medians of growth rates, inflation rates, and coefficient of variations of inflation for the 10 periods of time. The inflation variability is proxied by fiveyear coefficient of variation of inflation which is equal to the five-year standard deviations divided by respective five-year averages. The scatter graphs in Figure 1 and Figure 2 show the relationship between inflation and standard deviation of the inflation. It is also clear that there is no relationship between inflation and the coefficient of variation of the inflation.

\section{Table 1 here}

\section{ESTIMATION RESULTS}

\section{The threshold of inflation level}

The results of estimating the threshold of inflation level using whole sample and two subsamples (industrial and developing countries) are presented in Table 2. The range over which the search for the optimal threshold level is from 1 percent to 30 percent with the increment of 1 percent for all samples. We choose this range because Dornbusch and Fischer (1993) pointed out that there was an intermediate range of moderate rates of inflation around 15 percent to 30 percent. The minimum of RSSs occurs at the inflation level of 10 percent for 
all countries, 11 percent for developing, and 1 percent for developed countries. These results are quite close to those of Khan and Senhadji (2000).

\section{Table 2 here}

However, unlike the Khan and Senhadji (2000) results, the null hypothesis of no threshold effect is only rejected for the sample of all countries and developing countries. According to Kuang-Liang and Chi-Wei (2010) structural changes are common with long-run macroeconomic time-series data, so the empirical results may change depending on the selection of the sample period. In the next stage, we test the effect of inflation variability on growth, when the inflation rate exceeds the threshold level of inflation.

\section{The effect of inflation variability}

Conditional on the threshold of inflation level estimated in the first stage, and still using the method proposed by Hansen (1999), this stage test the effect of inflation variability on growth when the inflation is high (above the threshold level). This requires estimating equation (2), taking the threshold $\pi^{*}$ in the previous section as given, and computing the residual sum of squares for inflation variability ranging from 0.05 to 95 percentile of the coefficient of variation in each sample, with an increment of 0.05. As suggested by Hansen (1999), bootstrap method is used to test whether the variability effect is statistically significant across the three samples. The estimation results in Table 3 show that the null hypothesis of no inflation variability effects can be rejected for full sample and the sample of developing countries. Thus, the data supports the existence of an effect of inflation variability on growth in developing countries with high inflation (greater than 10 percent). However, there is no significant evidence that inflation variability has an effect on growth in developed countries. This is consistent with the research on G7 countries by Fountas and Karanasos (2007) or the research on industrial countries by Fountas (2010) who concluded that uncertainty about inflation is not detrimental to economic growth in these countries.

\section{Table 3 here}

Strikingly, the estimation results in Table 3 reveal not only a significant but also negative effect of inflation variability on growth in developing countries. Specifically, when inflation is higher than 10 percent in these countries, an increase in inflation is followed by a decrease in growth only if inflation is stable, i.e., coefficient of variation of inflation is lower than the 
threshold of variability. This can be explained as follows. Once the rate of inflation exceeds the threshold, further increases in inflation will lead to credit rationing (Azariadis and Smith 1996). Especially, due to the financial repression such as interest rate ceiling in developing countries, higher rates of inflation reduce saver's real rate of interest and discourage saving. Also, the financial system in developing countries depends largely on banking system as a major channel to mobilize investment capital (Fry 1995). As a result, the credit availability to investment is reduced, so growth is reduced by higher inflation. However, in the period of volatile inflation, the public hardly distinguish between permanent and temporary increases in inflation so they hardly recognize whether their earnings from saving are being undermined temporarily or permanently. If the public judge inflation is increasing only temporarily they might not want to change their saving behavior, and inflation does not have an effect on growth. This result may be explained using the argument by Bruno and Easterly (1996) that once inflation gets above a certain level, it is prone to accelerate suddenly. If the central bank keeps inflation stable when the inflation is already high, an increase in inflation may result in a reduction in growth because the public think that the central bank wants to raise the (stable) level of inflation. Correspondingly, if inflation is unstable, the public will not be clear whether this increase is temporary or permanent and the increase in inflation will have no impact on growth.

\section{ROBUSTNESS CHECK}

\section{Endogeneity of inflation}

The problem of reverse causation is dealt with by using instrumental variables. The set of instruments for inflation includes the lag of inflation, the lag of economic growth rate, the terms of trade growth rate, the lag of money growth rate, and time dummies. The results are presented in Table 4. The negative effect of inflation (above the threshold level) on growth is strengthened for developing countries but is still not significant for developed countries. The optimal threshold of inflation variability for developing countries is now 1.7, compared with 2.05 in the regression reported in Table 4.

Table 4 here 


\section{Sensitivity to the inclusion of interaction terms}

To illustrate the fact that if we use standard error to measure the inflation variability we cannot distinguish the effects on growth of the level of inflation from those of the variability of inflation, we re-estimate equation (2) using the standard deviation of inflation as a measure of inflation variability. The results are presented in Table 5. As expected, we cannot reject the hypothesis that the inflation variability is not detrimental to economic growth for the full sample and the sample of developing countries.

\section{Tables 5 and 6 here}

As discussed in Section I, the standard deviation of inflation is highly correlated with its level, making it difficult to distinguish the effects on growth of the level of inflation from the effects of the variability of inflation. Thus, we include that the interaction between inflation and the standard deviation of inflation into an estimation of equation (2) and get the results reported in Table 6. Adding the interaction variable does not change the significance of the variability effect of inflation on growth in developing countries as we saw in Table 3.

\section{CONCLUSIONS}

This paper examines the empirical effect of the variability of the inflation on growth when the inflation is high. The data cover 182 developing countries and 31 developed countries for the period 1961-2009. To measure the inflation variability and eliminate the multicollinearity between the standard deviation of inflation and its level, we use the coefficient of variation of the inflation over five years. Using the econometric technique of Hansen (1999), the empirical results suggest that (1) for developing countries, there is significant evidence for the negative effect of inflation variability on growth when the inflation rate is high; specifically, when the inflation is higher than 10 percent, an increase in inflation is followed by a decrease in growth only if inflation is stable; (2) for developed countries, there is no significant evidence that inflation variability is detrimental to growth. These results are quite robust with respect to the instrument variable (IV) estimation and the inclusion of the interaction between the standard deviation of inflation and its level. This result may explain the fact that once inflation gets above a certain level, it is prone to sudden acceleration. 


\section{Table 1}

Summary Statistics on Growth, Inflation and Inflation Variability

(5-year average observations)

\begin{tabular}{|c|c|c|c|c|}
\hline & & Growth rate & Inflation rate & CV of inflation rate \\
\hline \multirow{3}{*}{$1961-65$} & Mean & 7.891 & 5.966 & 1.273 \\
\hline & Median & 2.687 & 2.810 & 0.624 \\
\hline & No. of countries & 103 & 69 & 66 \\
\hline \multirow{3}{*}{ 1966-70 } & Mean & 3.363 & 8.024 & 0.829 \\
\hline & Median & 2.928 & 3.860 & 0.656 \\
\hline & No. of countries & 111 & 92 & 85 \\
\hline \multirow{3}{*}{ 1971-75 } & Mean & 2.603 & 12.495 & 0.635 \\
\hline & Median & 2.344 & 10.903 & 0.619 \\
\hline & No. of countries & 122 & 102 & 98 \\
\hline \multirow{3}{*}{ 1976-80 } & Mean & 2.233 & 15.944 & 0.569 \\
\hline & Median & 2.514 & 11.343 & 0.387 \\
\hline & No. of countries & 132 & 108 & 104 \\
\hline \multirow{3}{*}{ 1981-85 } & Mean & 0.523 & 42.541 & 0.723 \\
\hline & Median & 0.983 & 9.132 & 0.446 \\
\hline & No. of countries & 152 & 118 & 117 \\
\hline \multirow{3}{*}{ 1986-90 } & Mean & 1.672 & 53.295 & 1.089 \\
\hline & Median & 1.407 & 7.365 & 0.517 \\
\hline & No. of countries & 165 & 131 & 126 \\
\hline \multirow{3}{*}{ 1991-95 } & Mean & -0.109 & 116.028 & 0.638 \\
\hline & Median & 0.874 & 9.850 & 0.454 \\
\hline & No. of countries & 184 & 148 & 135 \\
\hline \multirow{3}{*}{ 1996-00 } & Mean & 2.645 & 19.941 & 1.056 \\
\hline & Median & 2.298 & 4.496 & 0.591 \\
\hline & No. of countries & 191 & 158 & 158 \\
\hline \multirow{3}{*}{ 2001-05 } & Mean & 2.888 & 8.123 & 0.818 \\
\hline & Median & 2.253 & 3.566 & 0.526 \\
\hline & No. of countries & 194 & 168 & 165 \\
\hline \multirow{3}{*}{ 2006-09 } & Mean & 2.754 & 6.478 & 0.705 \\
\hline & Median & 2.354 & 5.328 & 0.574 \\
\hline & No. of countries & 186 & 173 & 167 \\
\hline
\end{tabular}

Note: No. of countries is the number of non-missing observations. Except CV (coefficient of variation) of inflation, growth and inflation are 5-year averages. 
Table 2:

GLS with Fixed-Effects for the Threshold of Inflation Level

Dependent Variable: Growth

\begin{tabular}{|c|c|c|c|}
\hline Independent variables & $\begin{array}{c}\text { All } \\
\Pi^{*}=10\end{array}$ & $\begin{array}{c}\text { Developing } \\
\pi^{*}=11\end{array}$ & $\begin{array}{c}\text { Developed } \\
\pi^{*}=1\end{array}$ \\
\hline$d^{*}\left[\log (\pi)-\log \left(\pi^{*}\right)\right]$ & $\begin{array}{c}-1.7285^{\star * *} \\
(0.482)\end{array}$ & $\begin{array}{c}-1.6841^{* *} \\
(0.688)\end{array}$ & $\begin{array}{r}-1.8621 \\
(2.387)\end{array}$ \\
\hline Log of inflation & $\begin{array}{l}-0.0909 \\
(0.241)\end{array}$ & $\begin{array}{l}-0.0980 \\
(0.383)\end{array}$ & $\begin{array}{l}0.8768 \\
(2.339)\end{array}$ \\
\hline Investment over GDP & $\begin{array}{c}0.1159^{* \star *} \\
(0.040)\end{array}$ & $\begin{array}{c}0.1095^{\star *} \\
(0.049)\end{array}$ & $\begin{array}{l}0.0788^{*} \\
(0.046)\end{array}$ \\
\hline Government consumption expenditure over GDP & $\begin{array}{c}-0.1276^{* *} \\
(0.052)\end{array}$ & $\begin{array}{c}-0.1025^{\star *} \\
(0.052)\end{array}$ & $\begin{array}{c}-0.3864^{* * *} \\
(0.146)\end{array}$ \\
\hline Growth rate of terms of trade & $\begin{array}{c}0.0046^{* *} \\
(0.002)\end{array}$ & $\begin{array}{l}0.0047^{*} \\
(0.003)\end{array}$ & $\begin{array}{l}0.0010 \\
(0.002)\end{array}$ \\
\hline Log of initial GDP per capita & $\begin{array}{l}-0.7596 \\
(0.703)\end{array}$ & $\begin{array}{l}0.0794 \\
(1.059)\end{array}$ & $\begin{array}{l}-0.8921 \\
(1.776)\end{array}$ \\
\hline 1963 & $\begin{array}{r}-1.4937 \\
(1.044)\end{array}$ & $\begin{array}{r}-1.4944 \\
(1.620)\end{array}$ & \\
\hline 1968 & $\begin{array}{l}0.2956 \\
(0.868)\end{array}$ & $\begin{array}{l}-0.0818 \\
(1.203)\end{array}$ & $\begin{array}{l}1.3188 \\
(2.148)\end{array}$ \\
\hline 1973 & $\begin{array}{l}0.4757 \\
(0.666)\end{array}$ & $\begin{array}{l}0.4156 \\
(1.067)\end{array}$ & $\begin{array}{l}1.7456 \\
(1.747)\end{array}$ \\
\hline 1978 & $\begin{array}{l}0.0919 \\
(0.710)\end{array}$ & $\begin{array}{l}-0.7790 \\
(0.968)\end{array}$ & $\begin{array}{l}2.7817^{*} \\
(1.420)\end{array}$ \\
\hline 1983 & $\begin{array}{l}-0.9229 \\
(0.619)\end{array}$ & $\begin{array}{c}-1.6813^{* *} \\
(0.772)\end{array}$ & $\begin{array}{l}1.9395 \\
(1.294)\end{array}$ \\
\hline 1988 & $\begin{array}{c}1.7211^{* *} \\
(0.679)\end{array}$ & $\begin{array}{l}1.5459 \\
(1.059)\end{array}$ & $\begin{array}{c}2.9863^{* * *} \\
(0.870)\end{array}$ \\
\hline 1993 & $\begin{array}{l}-0.0432 \\
(0.420)\end{array}$ & $\begin{array}{l}-0.3319 \\
(0.684)\end{array}$ & $\begin{array}{l}1.2820^{*} \\
(0.713)\end{array}$ \\
\hline 1998 & $\begin{array}{l}0.7861^{*} \\
(0.427)\end{array}$ & $\begin{array}{l}0.1508 \\
(0.759)\end{array}$ & $\begin{array}{c}2.2525^{\star \star *} \\
(0.625)\end{array}$ \\
\hline 2003 & $\begin{array}{l}0.4554 \\
(0.403)\end{array}$ & $\begin{array}{l}0.3752 \\
(0.715)\end{array}$ & $\begin{array}{c}1.0586^{* * *} \\
(0.327)\end{array}$ \\
\hline Constant & $\begin{array}{l}8.0717 \\
(5.967)\end{array}$ & $\begin{array}{l}1.5424 \\
(7.927)\end{array}$ & $\begin{array}{l}16.2461 \\
(18.964)\end{array}$ \\
\hline Observations & 359 & 241 & 118 \\
\hline R-squared & 0.452 & 0.479 & 0.613 \\
\hline Number of countries & 116 & 87 & 29 \\
\hline
\end{tabular}

Note: Standard errors in parentheses are compute by bootstrap method. ${ }^{* *} p<0.01,{ }^{* *} p<0.05,{ }^{*} p<0.1$. 
Table 3

GLS with Fixed-Effects for the Threshold of Inflation Variability

Measured by Coefficient of Variation of Inflation

Dependent Variable: Growth

\begin{tabular}{|c|c|c|c|}
\hline Independent variables & $\begin{array}{c}\text { All } \\
C V^{*}=1.9 \\
\pi^{*}=10\end{array}$ & $\begin{array}{c}\text { Developing } \\
C V^{*}=2.05 \\
\pi^{*}=11\end{array}$ & $\begin{array}{c}\text { Developed } \\
\mathrm{CV}^{*}=.65 \\
\pi^{*}=1\end{array}$ \\
\hline dstable $\pi^{*}\left[\log (\pi)-\log \left(\pi^{*}\right)\right]$ & $\begin{array}{l}-1.133^{* * *} \\
(0.39)\end{array}$ & $\begin{array}{l}-0.964^{*} \\
(0.49)\end{array}$ & $\begin{array}{l}-1.456 \\
(1.93)\end{array}$ \\
\hline dunstable $\pi^{*}\left[\log (\pi)-\log \left(\pi^{*}\right)\right]$ & $\begin{array}{l}-2.978 \\
(2.71)\end{array}$ & $\begin{array}{l}-2.911 \\
(6.56)\end{array}$ & $\begin{array}{l}-0.922 \\
(1.99)\end{array}$ \\
\hline $\log (\pi)$ & $\begin{array}{l}-0.243 \\
(0.22)\end{array}$ & $\begin{array}{l}-0.352 \\
(0.34)\end{array}$ & $\begin{array}{c}0.669 \\
(1.85)\end{array}$ \\
\hline Investment over GDP & $\begin{array}{l}0.146^{\star * *} \\
(0.04)\end{array}$ & $\begin{array}{l}0.151^{* * *} \\
(0.05)\end{array}$ & $\begin{array}{c}0.067 \\
(0.05)\end{array}$ \\
\hline Government consumption expenditure over GDP & $\begin{array}{l}-0.127^{* *} \\
(0.06)\end{array}$ & $\begin{array}{l}-0.106^{* *} \\
(0.05)\end{array}$ & 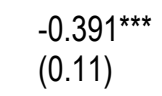 \\
\hline Terms of trade growth & $\begin{array}{l}0.004^{* *} \\
(0.00)\end{array}$ & $\begin{array}{c}0.003 \\
(0.00)\end{array}$ & $\begin{array}{c}0.000 \\
(0.00)\end{array}$ \\
\hline Log of initial GDP per capita & $\begin{array}{l}-1.053 \\
(0.76)\end{array}$ & $\begin{array}{l}-0.367 \\
(1.17)\end{array}$ & $\begin{array}{l}-0.416 \\
(1.01)\end{array}$ \\
\hline 1963 & $\begin{array}{l}-1.549^{*} \\
(0.87)\end{array}$ & $\begin{array}{l}-1.648 \\
(1.45)\end{array}$ & \\
\hline 1968 & $\begin{array}{c}0.238 \\
(0.69)\end{array}$ & $\begin{array}{l}-0.112 \\
(1.10)\end{array}$ & $\begin{array}{c}1.584 \\
(1.48)\end{array}$ \\
\hline 1973 & $\begin{array}{c}0.360 \\
(0.64)\end{array}$ & $\begin{array}{c}0.420 \\
(0.96)\end{array}$ & $\begin{array}{l}1.907^{*} \\
(1.07)\end{array}$ \\
\hline 1978 & $\begin{array}{l}-0.025 \\
(0.62)\end{array}$ & $\begin{array}{l}-0.852 \\
(1.14)\end{array}$ & 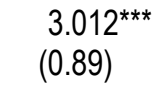 \\
\hline 1983 & $\begin{array}{l}-1.068^{*} \\
(0.58)\end{array}$ & $\begin{array}{l}-1.831^{\text {** }} \\
(0.74)\end{array}$ & $\begin{array}{l}1.808^{* *} \\
(0.90)\end{array}$ \\
\hline 1988 & $\begin{array}{l}1.524^{* \star *} \\
(0.54)\end{array}$ & $\begin{array}{c}1.242 \\
(0.95)\end{array}$ & $\begin{array}{l}3.240^{* * *} \\
(0.60)\end{array}$ \\
\hline 1993 & $\begin{array}{c}0.229 \\
(0.41)\end{array}$ & $\begin{array}{c}0.149 \\
(0.66)\end{array}$ & $\begin{array}{l}1.351^{\text {***}} \\
(0.50)\end{array}$ \\
\hline 1998 & $\begin{array}{c}0.757^{*} \\
(0.42)\end{array}$ & $\begin{array}{r}0.117 \\
(0.62)\end{array}$ & $\begin{array}{l}2.397^{\star * *} \\
(0.54)\end{array}$ \\
\hline 2003 & $\begin{array}{c}0.436 \\
(0.38)\end{array}$ & $\begin{array}{r}0.330 \\
(0.68)\end{array}$ & 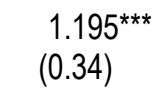 \\
\hline Constant & $\begin{array}{l}9.908^{*} \\
(5.76)\end{array}$ & $\begin{array}{c}4.213 \\
(8.38)\end{array}$ & $\begin{array}{c}11.496 \\
(10.87)\end{array}$ \\
\hline Observations & 359 & 241 & 118 \\
\hline R-squared & 0.516 & 0.555 & 0.636 \\
\hline Number of countries & 116 & 87 & 29 \\
\hline
\end{tabular}

Note: $\mathrm{CV}^{*}$ is the optimal threshold of the coefficient of variation $(\mathrm{CV})$ of inflation yields the smallest $\mathrm{RSS}$. Standard errors in parentheses are compute by bootstrap method. ${ }^{* * *} p<0.01,{ }^{* *} p<0.05,{ }^{*} p<0.1$. 
Table 4

2SLS with Fixed-Effects for the Threshold of Inflation Variability

Dependent Variable: Growth

\begin{tabular}{|c|c|c|c|}
\hline VARIABLES & $\begin{array}{c}\text { All } \\
\mathrm{CV}^{*}=1.7 \\
\Pi^{*}=10\end{array}$ & $\begin{array}{c}\text { Developing } \\
\begin{array}{c}C V^{*}=1.7 \\
\pi^{*}=11\end{array}\end{array}$ & $\begin{array}{c}\text { Developed } \\
C^{*}=.4 \\
\pi^{*}=1\end{array}$ \\
\hline dstable $\pi^{*}\left[\log (\pi)-\log \left(\pi^{*}\right)\right]$ & $\begin{array}{l}-0.973^{* *} \\
(0.46)\end{array}$ & $\begin{array}{l}-1.004^{* *} \\
(0.48)\end{array}$ & $\begin{array}{l}-2.457 \\
(3.28)\end{array}$ \\
\hline dunstable $\pi^{*}\left[\log (\pi)-\log \left(\pi^{*}\right)\right]$ & $\begin{array}{r}0.391 \\
(0.80)\end{array}$ & $\begin{array}{c}0.448 \\
(0.70)\end{array}$ & $\begin{array}{l}-3.034 \\
(3.05)\end{array}$ \\
\hline $\log (\pi)$ & $\begin{array}{l}-0.157 \\
(0.25)\end{array}$ & $\begin{array}{l}-0.098 \\
(0.33)\end{array}$ & $\begin{array}{l}2.456 \\
(2.54)\end{array}$ \\
\hline Investment over GDP & $\begin{array}{l}0.108^{* *} \\
(0.05)\end{array}$ & $\begin{array}{c}0.115^{\star} \\
(0.06)\end{array}$ & $\begin{array}{c}0.312 \\
(0.21)\end{array}$ \\
\hline Government consumption expenditure over GDP & $\begin{array}{l}-0.146^{* *} \\
(0.06)\end{array}$ & $\begin{array}{l}-0.154^{\star *} \\
(0.06)\end{array}$ & $\begin{array}{l}-0.030 \\
(0.33)\end{array}$ \\
\hline Terms of trade growth & $\begin{array}{l}0.009^{* *} \\
(0.00)\end{array}$ & $\begin{array}{l}0.010^{* *} \\
(0.00)\end{array}$ & $\begin{array}{c}0.006 \\
(0.01)\end{array}$ \\
\hline Log of initial GDP per capita & $\begin{array}{l}-1.213 \\
(1.07)\end{array}$ & $\begin{array}{l}-0.480 \\
(1.26)\end{array}$ & $\begin{array}{l}-2.132 \\
(4.06)\end{array}$ \\
\hline 1963 & $\begin{array}{l}-2.257 \\
(1.51)\end{array}$ & $\begin{array}{l}-2.537 \\
(1.88)\end{array}$ & \\
\hline 1968 & $\begin{array}{l}-0.818 \\
(1.08)\end{array}$ & $\begin{array}{l}-0.473 \\
(1.26)\end{array}$ & $\begin{array}{r}1.074 \\
(3.46)\end{array}$ \\
\hline 1973 & $\begin{array}{l}-0.170 \\
(0.99)\end{array}$ & $\begin{array}{c}0.182 \\
(0.94)\end{array}$ & $\begin{array}{l}-0.112 \\
(3.68)\end{array}$ \\
\hline 1978 & $\begin{array}{l}-0.741 \\
(1.06)\end{array}$ & $\begin{array}{l}-1.062 \\
(1.22)\end{array}$ & $\begin{array}{c}0.125 \\
(3.93)\end{array}$ \\
\hline 1983 & $\begin{array}{l}-1.408 \\
(0.86)\end{array}$ & $\begin{array}{l}-1.720^{\star \star} \\
(0.82)\end{array}$ & $\begin{array}{c}1.714 \\
(1.95)\end{array}$ \\
\hline 1988 & $\begin{array}{c}0.305 \\
(1.16)\end{array}$ & $\begin{array}{r}0.391 \\
(1.23)\end{array}$ & $\begin{array}{c}2.029 \\
(2.09)\end{array}$ \\
\hline 1993 & $\begin{array}{r}0.481 \\
(0.68)\end{array}$ & $\begin{array}{r}0.447 \\
(0.69)\end{array}$ & $\begin{array}{l}-0.848 \\
(1.83)\end{array}$ \\
\hline 1998 & $\begin{array}{l}-0.281 \\
(0.72)\end{array}$ & $\begin{array}{l}-0.137 \\
(0.74)\end{array}$ & $\begin{array}{l}-0.002 \\
(2.71)\end{array}$ \\
\hline 2003 & $\begin{array}{l}-0.091 \\
(0.82)\end{array}$ & $\begin{array}{l}-0.133 \\
(1.06)\end{array}$ & $\begin{array}{c}0.741 \\
(1.19)\end{array}$ \\
\hline Constant & $\begin{array}{l}12.090 \\
(8.55)\end{array}$ & $\begin{array}{c}6.092 \\
(9.81)\end{array}$ & $\begin{array}{c}15.863 \\
(39.29)\end{array}$ \\
\hline Observations & 233 & 195 & 46 \\
\hline R-squared & 0.339 & 0.366 & 0.749 \\
\hline Number of countries & 93 & 79 & 16 \\
\hline
\end{tabular}

Note: $\mathrm{CV}^{*}$ is the optimal threshold of the coefficient of variation (CV) of inflation yields the smallest RSS. Standard errors in parentheses are compute by bootstrap method. ${ }^{* * *} p<0.01,{ }^{* *} p<0.05,{ }^{*} p<0.1$ 


\section{Table 5}

GLS with Fixed-Effects for the Threshold of Inflation Variability

Measured by Standard Deviation of Inflation

Dependent Variable: Growth

\begin{tabular}{|c|c|c|c|}
\hline VARIABLES & $\begin{array}{c}\text { All } \\
S D^{*}=20 \\
\Pi^{*}=10\end{array}$ & $\begin{array}{c}\text { Developing } \\
\qquad D^{*}=19 \\
\pi^{*}=11\end{array}$ & $\begin{array}{c}\text { Developed } \\
\qquad \begin{array}{c}S^{*}=7 \\
\pi^{*}=1\end{array}\end{array}$ \\
\hline$d^{\text {stable } \pi^{*}}\left[\log (\pi)-\log \left(\pi^{*}\right)\right]$ & $\begin{array}{l}-2.673^{* * *} \\
(0.71)\end{array}$ & $\begin{array}{l}-2.676^{* * *} \\
(0.81)\end{array}$ & $\begin{array}{r}-1.613 \\
(2.27)\end{array}$ \\
\hline$d^{\text {unstable } \pi^{*}}\left[\log (\pi)-\log \left(\pi^{*}\right)\right]$ & $\begin{array}{l}-1.761^{* * *} \\
(0.47)\end{array}$ & $\begin{array}{l}-1.774^{* * *} \\
(0.56)\end{array}$ & $\begin{array}{r}-1.050 \\
(2.31)\end{array}$ \\
\hline $\log (\pi)$ & $\begin{array}{r}-0.027 \\
(0.30)\end{array}$ & $\begin{array}{l}0.001 \\
(0.38)\end{array}$ & $\begin{array}{l}0.698 \\
(2.24)\end{array}$ \\
\hline Investment over GDP & $\begin{array}{l}0.112^{* * *} \\
(0.04)\end{array}$ & $\begin{array}{l}0.104^{* *} \\
(0.04)\end{array}$ & $\begin{array}{l}0.069 \\
(0.07)\end{array}$ \\
\hline Government consumption expenditure over GDP & $\begin{array}{c}-0.133^{\star *} \\
(0.06)\end{array}$ & $\begin{array}{l}-0.107^{*} \\
(0.06)\end{array}$ & $\begin{array}{l}-0.374^{* * *} \\
(0.13)\end{array}$ \\
\hline Terms of trade growth & $\begin{array}{l}0.005^{* * *} \\
(0.00)\end{array}$ & $\begin{array}{l}0.005^{* *} \\
(0.00)\end{array}$ & $\begin{array}{l}0.000 \\
(0.00)\end{array}$ \\
\hline Log of initial GDP per capita & $\begin{array}{l}-0.814 \\
(0.81)\end{array}$ & $\begin{array}{l}0.030 \\
(1.18)\end{array}$ & $\begin{array}{l}-0.055 \\
(1.32)\end{array}$ \\
\hline Constant & $\begin{array}{l}7.769 \\
(6.39)\end{array}$ & $\begin{array}{l}1.687 \\
(7.94)\end{array}$ & $\begin{array}{c}9.767 \\
(13.51)\end{array}$ \\
\hline Observations & 359 & 241 & 118 \\
\hline R-squared & 0.459 & 0.485 & 0.641 \\
\hline Number of countries & 116 & 87 & 29 \\
\hline \multirow{2}{*}{$\begin{array}{l}\text { The bootstrap on difference in coefficients of } \\
d^{\text {stable } \pi^{*}}\left[\log (\pi)-\log \left(\pi^{*}\right)\right] \text { and } d^{\text {unstable } \pi^{*}}\left[\log (\pi)-\log \left(\pi^{*}\right)\right]\end{array}$} & -0.912 & -0.755 & $-0.563^{*}$ \\
\hline & $(0.56)$ & $(0.59)$ & $(0.31)$ \\
\hline
\end{tabular}

Note: SD* is the optimal threshold of standard deviation (SD) of inflation yields the smallest RSS.

Standard errors in parentheses are compute by bootstrap method. ${ }^{* *} p<0.01,{ }^{* *} p<0.05,{ }^{*} p<0.1$.

The estimated time dummies are not reported. 


\section{Table 6}

GLS with Fixed-Effects for the Threshold of Inflation Variability Measured by Standard Deviation of Inflation with Interaction

Dependent Variable: Growth

\begin{tabular}{|c|c|c|c|}
\hline & $\begin{array}{c}\text { All } \\
S D^{*}=20\end{array}$ & $\begin{array}{c}\text { Developing } \\
S D^{*}=19\end{array}$ & $\begin{array}{c}\text { Developed } \\
S D^{*}=2\end{array}$ \\
\hline VARIABLES & $\pi^{*}=10$ & $\pi^{*}=11$ & $\pi^{*}=1$ \\
\hline High and stable inflation & $\begin{array}{l}-2.136^{\star * \star} \\
(0.71)\end{array}$ & $\begin{array}{l}-1.893^{* *} \\
(0.75)\end{array}$ & $\begin{array}{l}-2.465 \\
(1.94)\end{array}$ \\
\hline High and unstable inflation & $\begin{array}{l}-0.896^{\star *} \\
(0.45)\end{array}$ & $\begin{array}{l}-0.726 \\
(0.47)\end{array}$ & $\begin{array}{l}-2.732 \\
(1.93)\end{array}$ \\
\hline Log of inflation & $\begin{array}{l}-0.257 \\
(0.30)\end{array}$ & $\begin{array}{l}-0.333 \\
(0.33)\end{array}$ & $\begin{array}{r}1.149 \\
(1.82)\end{array}$ \\
\hline Inflation times s.d. of inflation & $\begin{array}{l}-0.000 \\
(0.00)\end{array}$ & $\begin{array}{l}-0.000 \\
(0.00)\end{array}$ & $\begin{array}{c}0.004 \\
(0.01)\end{array}$ \\
\hline Investment over GDP & $\begin{array}{l}0.142^{\star * \star} \\
(0.04)\end{array}$ & $\begin{array}{l}0.135^{* * *} \\
(0.04)\end{array}$ & $\begin{array}{l}0.105^{*} \\
(0.06)\end{array}$ \\
\hline Government consumption expenditure over GDP & $\begin{array}{l}-0.144^{* *} \\
(0.06)\end{array}$ & $\begin{array}{l}-0.114^{*} \\
(0.06)\end{array}$ & $\begin{array}{l}-0.394^{* * *} \\
(0.12)\end{array}$ \\
\hline Terms of trade growth & $\begin{array}{l}0.003^{*} \\
(0.00)\end{array}$ & $\begin{array}{l}0.003 \\
(0.00)\end{array}$ & $\begin{array}{r}0.000 \\
(0.00)\end{array}$ \\
\hline Log of initial GDP per capita & $\begin{array}{l}-0.936 \\
(0.73)\end{array}$ & $\begin{array}{l}-0.158 \\
(1.06)\end{array}$ & $\begin{array}{l}-0.222 \\
(1.39)\end{array}$ \\
\hline Constant & $\begin{array}{c}7.928 \\
(6.63)\end{array}$ & $\begin{array}{l}1.706 \\
(7.71)\end{array}$ & $\begin{array}{r}9.332 \\
(13.79)\end{array}$ \\
\hline Observations & 348 & 233 & 115 \\
\hline R-squared & 0.385 & 0.398 & 0.683 \\
\hline Number of countries & 115 & 86 & 29 \\
\hline The bootstrap on difference in coefficients of & $-1.240^{\star *}$ & -1.166 & 0.266 \\
\hline dstable $\pi^{*}\left[\log (\pi)-\log \left(\pi^{*}\right)\right]$ and dunstable $\pi^{*}\left[\log (\pi)-\log \left(\pi^{*}\right)\right]$ & $(0.49)$ & $(0.73)$ & $(0.21)$ \\
\hline
\end{tabular}

Note: SD* is the optimal threshold of standard deviation (SD) of inflation yields the smallest RSS.

Standard errors in parentheses are compute by bootstrap method. ${ }^{* * *} p<0.01,{ }^{* *} p<0.05,{ }^{*} p<0.1$.

The estimated time dummies are not reported. 
Figure 1: Scatter graph of inflation and 5-year standard deviation of inflation

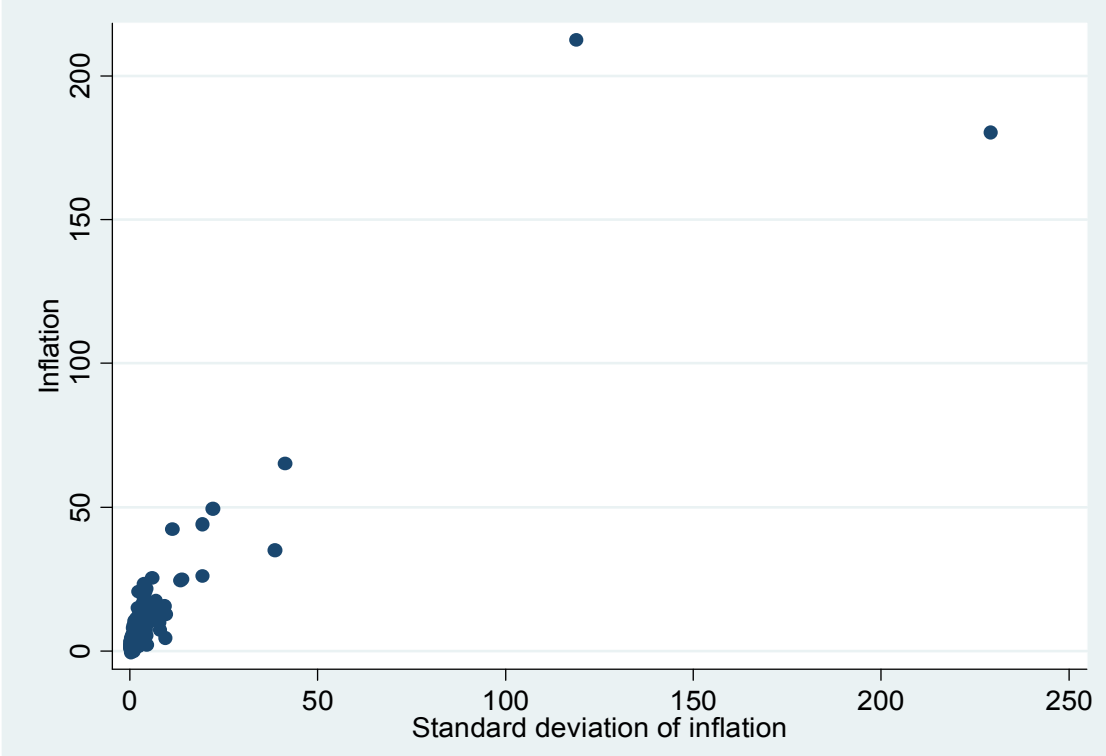

Figure 2: Scatter graph of inflation and 5-year coefficient of variation of inflation

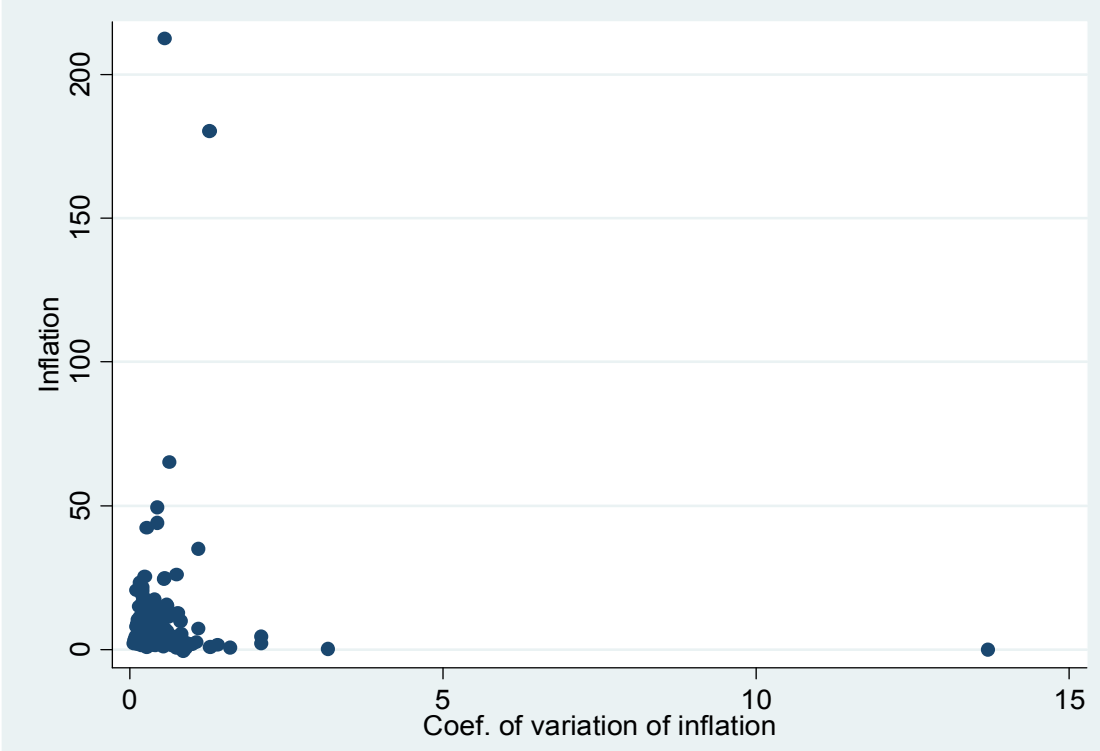




\section{References}

Azariadis, Costas \& Bruce D. Smith. 1996. Private information, money, and growth: indeterminacy, fluctuations, and Mundell-Tobin effect. Journal of Economic Growth 1: 309-32.

Ball, Laurence. 1990. Why does high inflation raise inflation uncertainty. NBER Working Paper Series (3224).

Barro, Robert J. 1995. Inflation and economic growth. NBER Working Paper Series (5326).

Bruno, Michael. 1995. Does inflation really lower growth? Finance \& Development 32(3): 35.

Bruno, Michael \& William Easterly. 1996. Inflation and growth: In search of a stable relationship. Review of dFederal Reserve Bank of St. Louis 78(3).

Dornbusch, Rudiger, \& Stanley Fischer. 1993. Moderate inflation. National Bureau of Economic Research Working Paper Series No. 3896 (published as The World Bank Economic Review, 7(1): 1-44 (January).

Dotsey, M. \& P. D. Sarte. 2000. Inflation uncertainty and growth in a cash-in-advance economy. Journal of Monetary Economics 45(3): 631-55.

Fischer, Stanley. 1993. The Role of macroeconomic factors in growth. Journal of Monetary Economics 32: 485-512.

Fountas, S. 2010. Inflation, inflation uncertainty and growth: Are they related? Economic Modelling 27(5): 896-899.

Fountas, Stilianos, \& Menelaos Karanasos. 2007. Inflation, output growth, and nominal and real uncertainty: Empirical evidence for the G7. Journal of International Money and Finance 26(2): 229-50.

Fry, Maxwell J. 1995. Money, interest, and banking in economic development: The Johns Hopkins University Press.

Hansen, Bruce. 1999. Threshold effects in non-dynamic panels: estimation, testing, and inference. Journal of Econometrics 93 (2):345-68.

Katsimbris, George M. 1985. The relationship between the inflation rate, its variability, and output growth variability: disaggregated international evidence. Journal of Money, Credit and Banking 17(2): 179-88.

Khan, Mohsin S. \& Abdelhak S. Senhadji. 2000. Threshold effects in the relationship between inflation and growth. IMF Working Paper.

Kuang-Liang, Chang \& He Chi-Wei. 2010. Does the magnitude of the effect of inflation uncertainty on output growth depend on the level of inflation? Manchester School 78(2):126-48.

Levi, Maurice D. \& John H. Makin. 1980. Inflation uncertainty and the Phillips Curve: Some empirical evidence. The American Economic Review 70(5): 1022-27.

Li, Min. 2006. Inflation and economic growth: threshold effects and transmission mechanisms. Department of Economics, University of Alberta.

Logue, Dennis E. \& Thomas D. Willett. 1976. A note on the relation between the rate and variability of inflation. Economica 43(170):151-8.

Narayan, Paresh Kumar, Seema Narayan \& Russell Smyth. 2009. Understanding the inflation-output nexus for China. China Economic Review 20(1):82-90.

Omay, Tolga \& Elif Öznur Kan. 2010. Re-examining the threshold effects in the inflation-growth nexus with cross-sectionally dependent non-linear panel: Evidence from six industrialized economies. Economic Modelling 27(5): 996-1005.

Sarel, Michael. 1995. Nonlinear effects of inflation on economic growth. IMF Working Paper.

Taylor, John B. 1993. Macroeconomic policy in a world economy: From econometric design to practical operation: W. W. Norton \& Company, Inc. 


\begin{tabular}{|c|c|c|c|}
\hline \multicolumn{4}{|c|}{ Appendix: List of Countries in Sample } \\
\hline Developing countries & Developing countries & Developing countries & Developed countries \\
\hline Afghanistan & Ghana & Nicaragua & Australia \\
\hline Albania & Gibraltar & Niger & Austria \\
\hline Algeria & Greenland & Nigeria & Belgium \\
\hline American Samoa & Grenada & Northern Mariana Islands & Canada \\
\hline Andorra & Guam & Oman & Czech Republic \\
\hline Angola & Guatemala & Pakistan & Denmark \\
\hline Antigua \& Barbuda & Guinea & Palau & Estonia \\
\hline Argentina & Guinea-Bissau & Panama & Finland \\
\hline Armenia & Guyana & Papua New Guinea & France \\
\hline Aruba & Haiti & Paraguay & Germany \\
\hline Azerbaijan & Honduras & Peru & Greece \\
\hline Bahamas, The & Hong Kong SAR, China & Philippines & Hungary \\
\hline Bahrain & India & Puerto Rico & Iceland \\
\hline Bangladesh & Indonesia & Qatar & Ireland \\
\hline Barbados & Iran, Islamic Rep. & Romania & Israel \\
\hline Belarus & Iraq & Russian Federation & Italy \\
\hline Belize & Isle of Man & Rwanda & Japan \\
\hline Benin & Jamaica & Samoa & Korea, Rep. \\
\hline Bermuda & Jordan & San Marino & Luxembourg \\
\hline Bhutan & Kazakhstan & Sao Tome \& Principe & Netherlands \\
\hline Bolivia & Kenya & Saudi Arabia & New Zealand \\
\hline Bosnia \& Herzegovina & Kiribati & Senegal & Norway \\
\hline Botswana & Korea, Dem. Rep. & Serbia & Poland \\
\hline Brazil & Kosovo & Seychelles & Portugal \\
\hline Brunei Darussalam & Kuwait & Sierra Leone & Slovak Republic \\
\hline Bulgaria & Kyrgyz Republic & Singapore & Slovenia \\
\hline Burkina Faso & Lao PDR & Solomon Islands & Spain \\
\hline Burundi & Latvia & Somalia & Sweden \\
\hline Cambodia & Lebanon & South Africa & Switzerland \\
\hline Cameroon & Lesotho & Sri Lanka & United Kingdom \\
\hline Cape Verde & Liberia & St. Kitts \& Nevis & United States \\
\hline Cayman Islands & Libya & St. Lucia & \\
\hline Central African Republic & Liechtenstein & St. Vincent \& the Grenadines & \\
\hline Chad & Lithuania & Sudan & \\
\hline Channel Islands & Macao SAR, China & Suriname & \\
\hline Chile & Macedonia, FYR & Swaziland & \\
\hline China & Madagascar & Syrian Arab Republic & \\
\hline Colombia & Malawi & Tajikistan & \\
\hline Comoros & Malaysia & Tanzania & \\
\hline Congo, Dem. Rep. & Maldives & Thailand & \\
\hline Congo, Rep. & Mali & Timor-Leste & \\
\hline Costa Rica & Malta & Togo & \\
\hline Cote d'Ivoire & Marshall Islands & Tonga & \\
\hline Croatia & Mauritania & Trinidad \& Tobago & \\
\hline Cuba & Mauritius & Tunisia & \\
\hline Cyprus & Mayotte & Turkey & \\
\hline Djibouti & Mexico & Turkmenistan & \\
\hline Dominica & Micronesia, Fed. Sts. & Turks \& Caicos Islands & \\
\hline Dominican Republic & Moldova & Tuvalu & \\
\hline Ecuador & Monaco & Uganda & \\
\hline Egypt, Arab Rep. & Mongolia & Ukraine & \\
\hline El Salvador & Montenegro & United Arab Emirates & \\
\hline Equatorial Guinea & Morocco & Uruguay & \\
\hline Eritrea & Mozambique & Uzbekistan & \\
\hline Ethiopia & Myanmar & Vanuatu & \\
\hline Faeroe Islands & Namibia & Venezuela, RB & \\
\hline Fiji & Nepal & Vietnam & \\
\hline French Polynesia & Netherlands Antilles & Virgin Islands (U.S.) & \\
\hline Gabon & New Caledonia & West Bank \& Gaza & \\
\hline Gambia, The & Nicaragua & Yemen, Rep. & \\
\hline Georgia & New Caledonia & Zambia & \\
\hline & & Zimbabwe & \\
\hline
\end{tabular}


